\title{
Epidemiological aspects of visceral leishmaniasis in Jaciara, Mato Grosso, Brazil, 2003 to 2012
}

Aspectos epidemiológicos da leishmaniose visceral em Jaciara, Estado de Mato Grosso, Brasil, de 2003 a 2012

Veruska Nogueira de Brito ${ }^{1,2 *}$; Cenita Maria Oliveira ${ }^{3}$; Patrícia Lazari ${ }^{1}$; Valéria Régia Franco Sousa ${ }^{1}$

${ }^{1}$ Programa de Pós-graduação em Ciências Veterinárias, Faculdade de Agronomia, Medicina Veterinária e Zootecnia, Universidade Federal de Mato Grosso - UFMT, Cuiabá, MT, Brasil

${ }^{2}$ Laboratório de Entomologia, Secretaria Estadual de Saúde de Mato Grosso - SES-MT, Cuiabá, MT, Brasil

${ }^{3}$ Vigilância Ambiental em Saúde, Secretaria Municipal de Saúde, Jaciara, MT, Brasil

Received September 5, 2013

Accepted January 30, 2014

\begin{abstract}
Visceral leishmaniasis (VL) is caused by Leishmania (L.) infantum chagasi in the Americas. In Brazil, it is transmitted by sandflies of the species Lutzomyia longipalpis and L. cruzi, and dogs are the main domestic reservoirs. The aim of this study was to analyze data relating to VL transmission in Jaciara, state of Mato Grosso, and discuss vector distribution, domestic reservoirs, and human cases that occurred between 2003 and 2012. The data for analysis were obtained from the Notifiable Diseases Information System (human), the State Health Department's Environmental Monitoring Agency (canine data) and the State Health Department's Entomology Laboratory (sandfly data). Over this period, Jaciara had 19 autochthonous human cases (12 males and seven females), with one death 2,273. Out of the 7,545 dogs tested by enzyme immunoassay and indirect immunofluorescence were positive. The sandflies collected comprised 5,015 individuals belonging to 24 species, with a predominance of L. whitmani followed by L. cruzi. The results showed that the parasite has frequent circulation and that the vector $L$. cruzi is widely distributed over all months, thus suggesting that transmission may occur at any time of the year.
\end{abstract}

Keywords: Visceral leishmaniasis (VL), Lutzomyia cruzi, Lutzomyia whitmani, Canine Reservoir.

\section{Resumo}

A leishmaniose visceral (LV), causada nas Américas pelo protozoário Leishmania (L.) infantum chagasi, transmitida no Brasil por flebotomíneos das espécies Lutzomyia longipalpis e $L$. cruzi, tem os cães como principais reservatórios domésticos. O objetivo deste trabalho foi analisar os dados relacionados à transmissão da LV, em Jaciara (MT), e discutir a respeito da distribuiçáo do vetor, reservatório doméstico e os casos humanos ocorridos no período de 2003 a 2012. Os dados para análise foram obtidos do Sistema de Informaçóes de Agravos de Notificaçáa (humanos), da Vigilância Ambiental da Secretaria Estadual de Saúde (caninos) e do Laboratório de Entomologia da Secretaria Estadual de Saúde (flebotomíneos). Jaciara apresentou 19 casos autóctones, 12 do sexo masculino e sete do sexo feminino, com um óbito. Dos 7.545 cães testados por imunoensaio enzimático e reação de imunofluorescência indireta, 2.273 foram reagentes. Os flebotomíneos coletados totalizaram 5.015 indivíduos pertencentes a 24 espécies com predomínio de L. whitmani seguido por $L$. cruzi. Os resultados demonstraram circulaçấo frequente do parasito e a ampla distribuiçâo do vetor $L$. cruzi com frequência em todos os meses, sugerindo que a transmissão possa ocorrer em qualquer época do ano.

Palavras-chave: Leishmaniose Visceral (LV), Lutzomyia cruzi, Lutzomyia whitmani, Reservatório Canino.

\section{Introduction}

Visceral leishmaniasis $(\mathrm{VL})$ is a zoonotic disease characterized by systemic involvement of chronic disease, which if untreated results in death in $90 \%$ of the cases. VL is caused by different species of

\footnotetext{
* Corresponding author: Veruska Nogueira de Brito

Rua Treze de Junho, 1342, Centro Sul, CEP 78020-000, Cuiabá, MT, Brasil

e-mail: veruskamarcelo@hotmail.com
}

the genus Leishmania, and in the Americas, $L$. (L.) infantum chagasi is the etiological agent for the disease (MAIA-ELKHOURY et al., 2008).

Transmission occurs through an insect belonging to the family Psychodidae, genus Lutzomyia, and Lutzomyia longipalpis is the main vector species in Brazil. In 1998, L. cruzi was identified as a vector in Corumbá, Mato Grosso do Sul (MS) (SANTOS et al., 1998). 
Missawa and Maciel (2006) detected the presence of L. cruzi in 24 municipalities in the state of Mato Grosso (MT). L. cruzi has frequently been recorded in Jaciara, MT, whereas L. longipalpis is absent, as seen in Corumbá and Ladário, MS. Surveys conducted in Jaciara in 2011 confirmed that natural infection by Leishmania was present in L. cruzi, using the PCR technique on three pools of 10 females each (MISSAWA et al., 2011).

Among the pets that may harbor the etiological agent for VL, dogs are the most important in epidemiological terms. They serve as a feeding source for the vector and end up facilitating contact between these insects and humans. Their high population density and susceptibility to $L$. (L.) infantum chagasi are factors that make dogs the main domestic reservoir for VL in the Americas (REY, 2001). Mestre and Fontes (2007) evaluated the canine serological surveys conducted in Mato Grosso from 1998 to 2005, and demonstrated that the municipality of Jaciara had the highest number of reactive dogs, with an infection rate of $40 \%$. The aim of the present study was to survey the data relating to VL transmission in Jaciara, with discussion of the vector distribution, domestic reservoirs and human cases that occurred between 2003 and 2012.

\section{Materials and Methods}

\section{Study area}

The municipality of Jaciara MT, is situated $145 \mathrm{~km}$ from the state capital (Cuiabá), at the latitude $15^{\circ} 57^{\prime} 22^{\prime \prime}$ south and the longitude $54^{\circ} 57^{\prime} 48^{\prime \prime}$ west, with an estimated population in 2012 of 25,927 inhabitants distributed across an area of $1,654 \mathrm{~km}^{2}$. It is located in the Brazilian savanna biome (cerrado), with a hot and subhumid tropical climate with four dry months, from May to August. The municipality is a prominent center for ecotourism activities and leisure activities (MISSAWA et al., 2011).

\section{Human cases}

Information on confirmed cases of human VL was obtained from the Notifiable Diseases Information System (SINAN), which was made available by the Epidemiological Monitoring Sector of the Municipal Health Department of Jaciara, covering the period from 2003 to 2012. The incidence rate per 100,000 inhabitants was based on records of confirmed cases divided by the estimated population for each year, provided by the Instituto Brasileiro de Geografia e Estatísticaa (IBGE, 2012).

\section{Canine cases}

Serological data relating to detection of canine VL, covering the period from 2003 to 2012, were obtained from the MT State Health Department's Environmental Monitoring Agency. In accordance with the recommendations from the Ministry of Health at that time, this Agency was using the enzyme immunoassay (ELISA) as a screening test and indirect immunofluorescence for confirmation.
We calculated the positivity index (ratio between the number of positive animals and the number of animals examined) instead of the canine prevalence (ratio between the number of positive dogs and the total number of dogs in the municipality). This was because many of the dogs were examined through spontaneous demand, in which the owners sough the environmental monitoring services when their pets were already sick, thus resulting in high rates of positivity.

\section{Entomological data}

Secondary entomological data provided by the Entomology Laboratory of the MT State Department of Health were used. These data resulted from separate surveys conducted in November 2003, January, March, August and September 2004, May 2006, November 2008, July 2009, July 2010 to June 2011, August to December 2011, October and December 2012 and from monitoring conducted between April 2005 and April 2007. The districts chosen to participate in the monitoring (São Sebastião, Center, Santa Luzia, São Lourenço, Planalto, Santo Antônio, Jardim Aurora and Santa Rita) were the ones in which presence of human VL cases and canine reservoirs were recorded. These insects were collected using CDC light traps, installed in peridomestic suggestive for the occurrence vector such as the presence of plants, accumulation of organic matter, the presence of pets (dogs, chickens, pigs, horses, etc); at dusk and gathered in around 12 hours later, on three consecutive days for the survey and four days in the case of monitoring. The specimens were screened, clarified and identified in accordance with the taxonomic key of Young and Duncan (1994). The frequency was calculated for each species corresponding to the number of individuals of a given species in relation to the total number of specimens collected over the course of the study.

\section{Results}

During the study period, the municipality of Jaciara had 19 autochthonous human cases of VL (12 men and seven women) in the years 2003, 2004, 2005, 2008, 2011 and 2012, with a death. Nine of the individuals affected were children under seven years of age and the remaining patients were aged between 17 and 55 years. Only one person live in the rural zone of the municipality, and the rest were residents of the following districts: Santo Antônio, Center, Santa Luzia, São Sebastião, Jardim Aurora, João de Barro and Planalto. Santo Antônio was the district with greatest number of notifications, accounting for seven of them. Out of the 19 cases of VL, 10 were reported in the months of May, June and July, and the latter month presented four cases. The average incidence was 12.2 cases per 100,000 individuals (Table 1 ).

The canine serological investigations encompassed 7,545 animals, of which 2,273 were reactive, thus resulting in an average positivity rate of around $35.6 \%$ (Table 2). Taking into account only the years with the highest numbers of animals examined, i.e. from 2005 to 2012 , the average positivity rate was $28.1 \%$.

Table 2 shows that there was no information regarding the number of dogs euthanized in the years 2003 to 2006 and 2010. 
Table 1. Data on human cases of visceral leishmaniasis (VL) in the municipality of Jaciara, Mato Grosso, Brazil, 2003-2012.

\begin{tabular}{cccc}
\hline Year & $\begin{array}{c}\text { Estimated } \\
\text { population }\end{array}$ & $\begin{array}{c}\text { No of cases of } \\
\text { VL }\end{array}$ & Incidence* $^{*}$ \\
\hline 2003 & 25,337 & 03 & 11.8 \\
2004 & 25,826 & 04 & 15.5 \\
2005 & 26,929 & 01 & 3.7 \\
2006 & 27,494 & - & - \\
2007 & 28,055 & - & - \\
2008 & 25,745 & 03 & 11.6 \\
2009 & 25,925 & - & - \\
2010 & 25,647 & - & - \\
2011 & 25,790 & 03 & 11.6 \\
2012 & 25,927 & 05 & 19.3 \\
Total & - & 19 & - \\
\hline
\end{tabular}

*per 100,000 inhabitants; No - number.

Table 2. Canine serological survey in Jaciara, Mato Grosso, Brazil, 2003-2012.

\begin{tabular}{ccccc}
\hline Year & $\begin{array}{c}\text { No of dogs } \\
\text { examined }\end{array}$ & $\begin{array}{c}\text { No of } \\
\text { seropositive } \\
\text { dogs }\end{array}$ & $\begin{array}{c}\text { Positivity } \\
\text { rate } \%\end{array}$ & $\begin{array}{c}\text { No of dogs } \\
\text { euthanized }\end{array}$ \\
\hline 2003 & 73 & 51 & 70.0 & - \\
2004 & 211 & 129 & 61.0 & - \\
2005 & 1085 & 270 & 25.0 & - \\
2006 & 824 & 305 & 37.0 & - \\
2007 & 1266 & 248 & 19.5 & 203 \\
2008 & 980 & 148 & 15.0 & 131 \\
2009 & 872 & 213 & 24.4 & 49 \\
2010 & 330 & 45 & 13.6 & - \\
2011 & 919 & 422 & 45.9 & 357 \\
2012 & 985 & 442 & 44.8 & 205 \\
Total & 7,545 & 2,273 & - & 945 \\
\hline
\end{tabular}

No - number; \% - percentage.

Even in subsequent years, the numbers of such procedures were lower than the number of positive dogs. Nonetheless, this is one of the main VL control measures recommended by the Ministry of Health, and it has the aim of eliminating the source of vector infection.

Entomological surveys on the vector collected 5,015 sandflies and of these, 2,793 were gathered through the monitoring. A total of 24 species were identified; $64,6 \%$ of the specimens were male and $35,4 \%$ were female (Table 3 ). The species with the highest number of individuals was Lutzomyia whitmani, which is the vector of American cutaneous leishmaniasis (ACL), followed by L. cruzi, the vector of visceral leishmaniasis (VL).

Over the two years of monitoring, sandfly vectors for both ACL and VL were found to be present every month, even in months that are less favourable for their development, i.e. during very dry periods and during the months of heavy rain. Figure 1 shows that there were evident increases in the density of these insects in the months that followed the rainy season (which covered, April, May and June). L. cruzi was only predominant in March.

Jaciara is a municipality with tourist potential focusing on ecotourism. Thus, many of its neighborhoods comprise heavily vegetated areas, especially on the banks of its streams and waterfalls. In addition, there are smallholdings with livestock such as pigs,
Table 3. Species of sandflies collected in surveys and monitoring between 2003 and 2012, Jaciara, Mato Grosso, Brazil.

\begin{tabular}{|c|c|c|c|c|}
\hline Species & $\sigma$ & 우 & Total & $\begin{array}{c}\text { Frequency } \\
\% \\
\end{array}$ \\
\hline Brumptomyia brumpti & 41 & 52 & 93 & 1.85 \\
\hline Lutzomyia acanthopharynx & 03 & 03 & 06 & 0.12 \\
\hline Lutzomyia antunesi & 03 & 05 & 08 & 0.16 \\
\hline Lutzomyia carrerai carrerai & 01 & 02 & 03 & 0.06 \\
\hline Lutzomyia carmelinoi & 01 & - & 01 & 0.02 \\
\hline Lutzomyia cruzi & 1294 & 645 & 1,939 & 38.64 \\
\hline Lutzomyia dasymera & 01 & 01 & 02 & 0.04 \\
\hline Lutzomyia davisi & 08 & 08 & 16 & 0.32 \\
\hline Lutzomyia evandroi & 09 & 08 & 17 & 0.34 \\
\hline Lutzomyia flaviscutellata & 01 & - & 01 & 0.02 \\
\hline Lutzomyia hermanlenti & 02 & 07 & 09 & 0.18 \\
\hline Lutzomyia lenti & 08 & 02 & 10 & 0.20 \\
\hline Lutzomyia longipennis & - & 02 & 02 & 0.04 \\
\hline Lutzomyia lutziana & - & 01 & 01 & 0.02 \\
\hline Lutzomyia punctigeniculata & 03 & 06 & 09 & 0.18 \\
\hline Lutzomyia sallesi & 15 & 17 & 32 & 0.64 \\
\hline Lutzomyia saulensis & 01 & 02 & 03 & 0.06 \\
\hline Lutzomyia shannoni & 01 & 02 & 03 & 0.06 \\
\hline Lutomyia sordellii & 78 & 90 & 168 & 3.35 \\
\hline Lutzomyia teratodes & 02 & 05 & 07 & 0.14 \\
\hline Lutzomyi termitophila & 05 & 06 & 11 & 0.22 \\
\hline Lutzomyia walkeri & - & 01 & 01 & 0.02 \\
\hline Lutzomyia whitmani & 1762 & 910 & 2,672 & 53.3 \\
\hline Lutzomyia yuilli yuilli & 01 & - & 01 & 0.02 \\
\hline Total & 3,240 & 1,775 & 5,015 & 100.00 \\
\hline
\end{tabular}

chickens and cattle in areas close to the center of the municipalily, such as in the São Sebastião district. In the more peripheral districts, in addition to forested areas, there are many vacant plots of land containing rubble and decaying organic matter derived from leaves and fruits that fall to the ground. These features easily observed in the Santo Antônio, Planalto and Aurora districts. Out of the eight districts participating in the monitoring, only Aurora had no records of $L$. cruzi, although this species has been recorded later in this neighbourhood surveys conducted in 2011. The distribution of this species was seen to coincide with the human cases reported in the municipality (Figure 2).

\section{Discussion}

According to Maia-Elkhoury et al. (2008), between 2001 and 2005, visceral leishmaniasis was distributed across various age groups, but occurred most often among children under the age of 10 years $(56.7 \%)$, and $43.4 \%$ of cases were in children under five years of age. Prado et al. (2011) observed that in Montes Claros, state of Minas Gerais, more men were affected byVL (64\%), and this is compatible with an average of $61 \%$ found in Brazil.

Mestre and Fontes (2007) reported that VL Mato Grosso primarily affected males and children aged less than five years. Although the mean incidence in Jaciara is more than ten cases 
per 100,000 inhabitants, the municipality was classified at that time by the Ministry of Health (BRASIL, 2006) as an area of moderate transmission, i.e. an area in which the mean number of cases over the preceding five years was more than 2,4 . The results presented in our study are concordant with the literature regarding the ages and sex of individuals affected by the disease. The greater susceptibility of children is explained by their relative immunological immaturity, aggravated by the malnutrition commonly found in

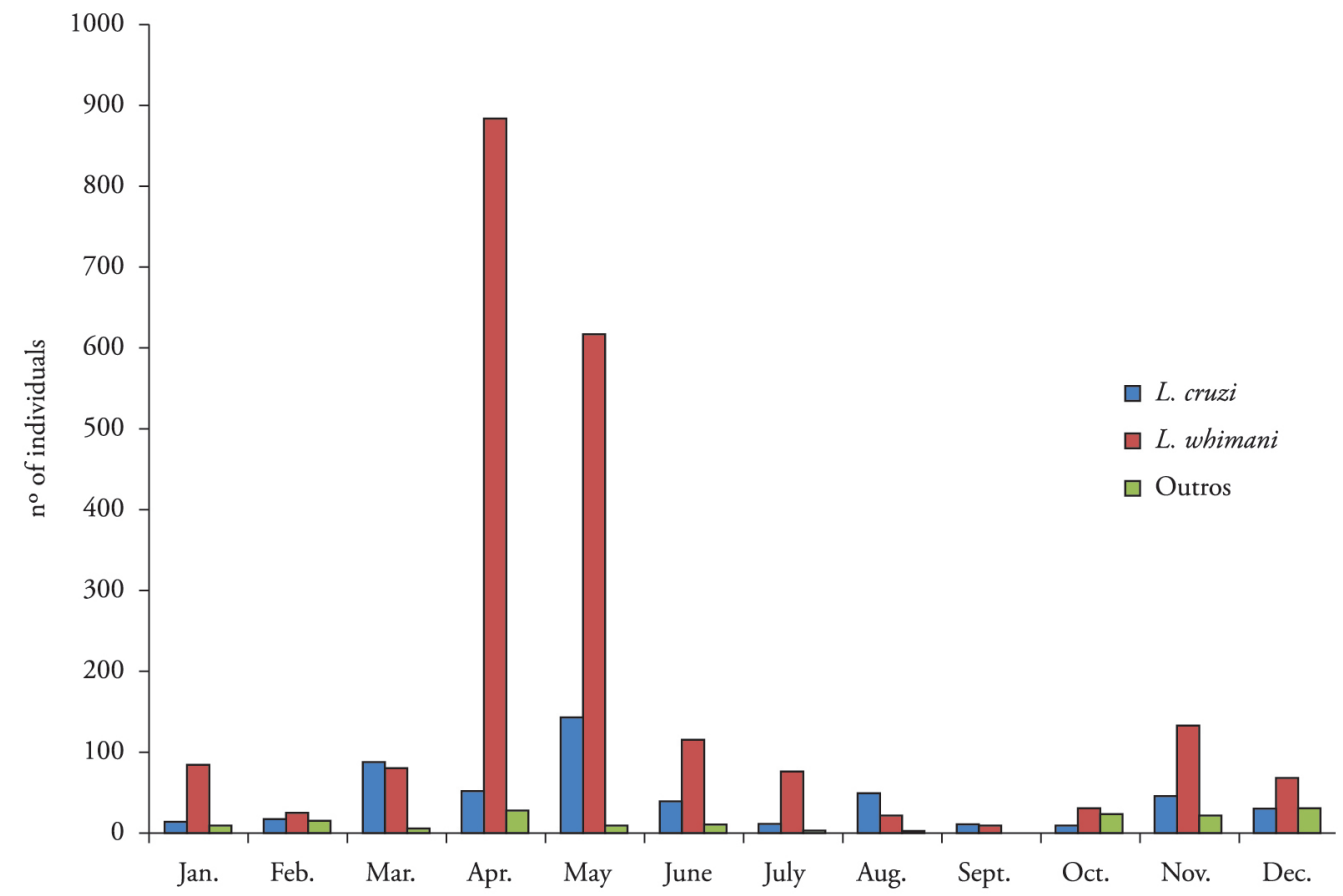

Figure 1. Monthly variation of the main species of sandflies collected during monitoring in Jaciara, Mato Grosso, from April 2005 to April 2007.

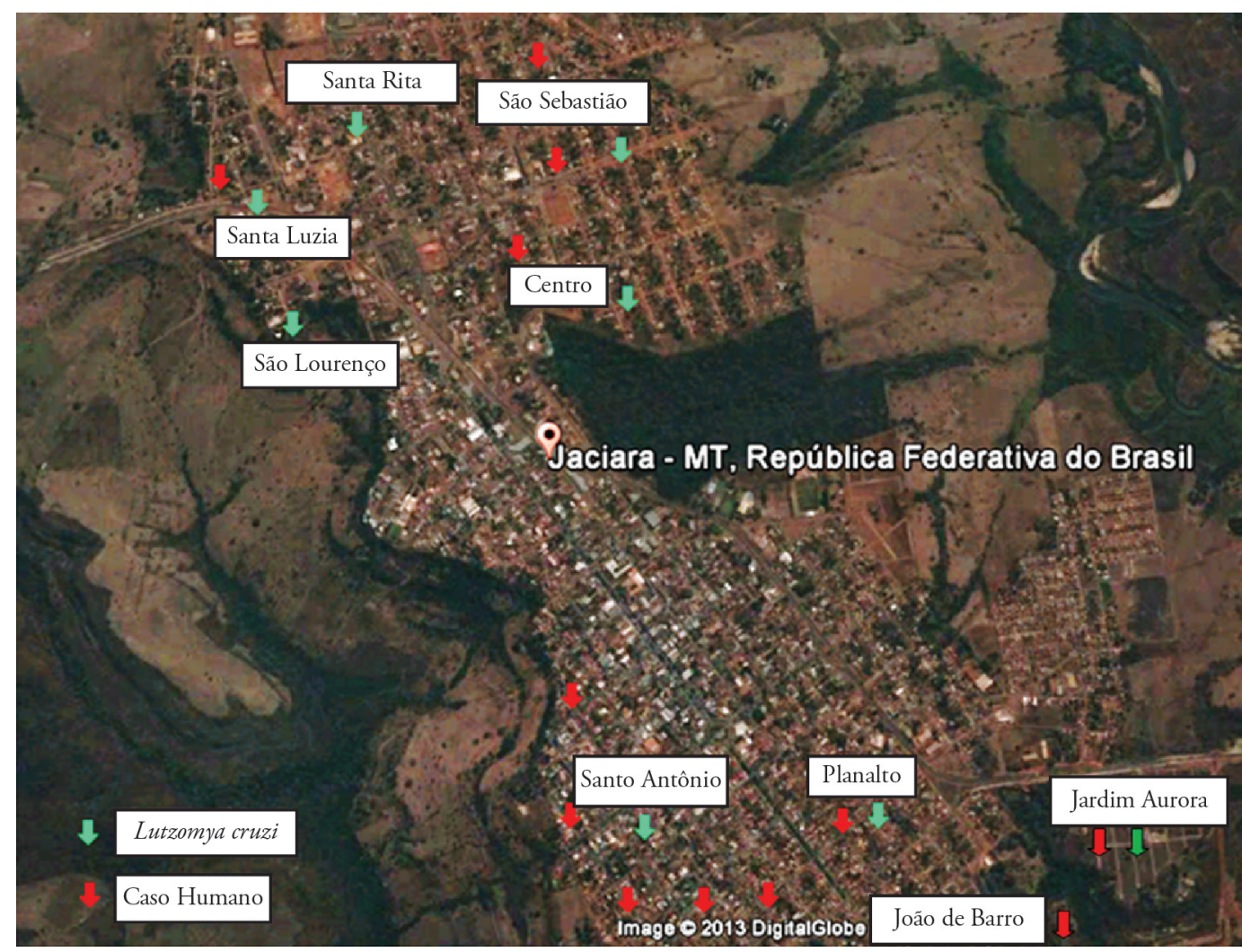

Figure 2. Spatial distribution of L. cruzi according to district surveyed in entomological monitoring and human cases that occurred in the municipality of Jaciara, Mato Grosso, Brazil, 2003-2012. 
endemic areas and even by the greater exposure to the vector in peridomestic areas (BRASIL, 2009).

Most of the human cases presented (52.6\%) were reported in May, June and July, i.e. the months immediately after the period of greatest vector density, which was April and May. However, in examining reports on 138 patients infected in the state of Mato Grosso, Mestre and Fontes (2007) noted that the monthly distribution was uneven, without any seasonal transmission pattern. This was probably due to the length of incubation of the disease, which is variable from patient to patient, as well as the time that patients take to seek medical attention after having been infected.

From analysis on Table 2, it can be seen that from the year 2005 onwards, serological surveys for canine VL became intensified due to reports of human cases in previous years. As the number of animals examined increased, the positivity rates became more representative. However, these rates have remained high, thus demonstrating that there is a need for integrated actions aimed at vector control and consequent reduction of the numbers of canine cases.

In a study in Cuiabá, MT, on 430 dogs from urban and rural locations, Almeida et al. (2012) found that the mean prevalence of dogs seropositive for visceral leishmaniasis was 22,1\%. In an endemic area of San Luis, state of Maranhão, Barbosa et al. (2010) observed a high frequency of positive dogs (67\%), and in the same state, Felipe et al. (2011) found a canine infection rate of $47.8 \%$ in the municipality of Raposa. The latter was, almost twice as high as the rate found by Guimarães et al. (2005) in another endemic area.

The number of sandfly species described in Jaciara shows that these insects present great faunal variety. Missawa and Maciel (2007) attributed the variety found in the state of Mato Grosso to the diversity of biomes such as savannah (cerrado), Pantanal, Amazon transition forest and Amazon forest, and this was also observed by Alves et al. (2012), in a study conducted in rural settlements in the municipality of Cáceres.

This diversity of sand flies in Jaciara differs from some other regions of the country. In Dracena in the state of São Paulo, over a one-year period, Rangel et al. (2012) collected 5,889 sandflies that were distributed between only two species, and 99.8\% were identified as Lutzomyia longipalpis. Costa et al. (2013) captured 24,226 sand flies in monthly collections over a one-year period in Passira, a municipality in Pernambuco. Despite this large number of individuals, only four species were identified, and $97.8 \%$ of them were L. longipalpis. In the municipality of Corumbá, state of Mato Grosso do Sul, in 1997, eight species were captured in the urban area, with predominance of $L$. cruzi in both domestic and peridomestic areas (GALATI et al., 1997). In Ponta Porã, entomological surveys between 2004 and 2008 resulted in 3,946 individuals represented by eight species, with predominance of L. longipalpis (ALMEIDA et al., 2010). In Três Lagoas, 14 species were recorded between 2000 and 2006, totaling 4,277 specimens collected, with $L$. longipalpis corresponding to 87\% (OLIVEIRA et al., 2010). Unlike these regions, faunal studies on these insects in Tocantins showed high species richness, with 48 species described in the municipality of Porto Nacional between 2004 and 2007, and revealing predominance of L. longipalpis, L. whitmani and L. sordellii (VILELA et al., 2011). In the Taquaruçu district, six months of research resulted in 767 sandfly specimens from 32 different species (MACHADO et al., 2012).

The VL control measures directed towards the vector that are recommended by the Ministry of Health focus on practices involving environmental management through tree pruning to enable light penetration, removal of organic matter and prohibition of animals such as pigs and chickens in backyards, thereby avoiding establishment of sandflies in the home environment. These procedures should be continuous and should be encouraged through health education. Even with high vector densities and high canine prevalence, chemical control is only indicated when human cases appear. In Jaciara, chemical control was applied soon after the onset of the cases. However, lack of public awareness regarding the precautions in the peridomestic area allowed these insects to continue to be present in these environments. Thus, it was observed that the activities were focused on eliminating seroreactive dogs. However, for operational reasons, this is not always carried out immediately.

The frequency and density of L. whitmani and L. cruzi in various districts of the municipality demonstrates the adaptation of these species to urban areas. According to information from the Environmental Surveillance Sector of Jaciara, despite the high density of $L$. whitmani, there were no reports of transmission of cutaneous leishmaniasis in the urban area. All the cases of this condition have been reported in rural and wild environments.

Although Jaciara only showed 19 human cases during the study period, the canine serological surveys demonstrated that the parasite presented frequent circulation, since numbers of seropositive dogs were recorded in all years of the study, with positivity rates ranging from 15 to $70 \%$. The difficulty in eliminating these animals, as demonstrated by the low number of dogs that were put down, in comparison with the number of positive dogs, certainly contributed towards the epidemiology of human cases, given that studies have indicated that canine infection precedes human infection. The wide distribution of the vector $L$. cruzi in this municipality and its occurrence in all months suggest that transmission can occur at any time of the year. However, the periods that follow the rains seem to favor proliferation of the insect, which increases the risk of infection.

\section{References}

Almeida ABPF, Sousa VRF, Cruz FACS, Dahroug MAA, Figueiredo FB, Madeira MF. Canine visceral leishmaniasis: seroprevalence and risk factors in Cuiabá, Mato Grosso, Brazil. Rev Bras Parasitol Vet 2012; 21(4): 359365. http://dx.doi.org/10.1590/S1984-29612012005000005

Almeida PS, Minzão ER, Minzão LD, Silva SR, Ferreira AD, Faccenda $\mathrm{O}$, et al. Aspectos ecológicos de flebotomíneos (Diptera: Psychodidae) em área urbana do município de Ponta Porã, Estado de Mato Grosso do Sul. Rev Soc Bras Med Trop 2010; 43(6): 723-727. PMid:21181032. http://dx.doi.org/10.1590/S0037-86822010000600025

Alves GB, Oshiro ET, Leite MC, Melão AV, Ribeiro LM, Mateus NLF, et al. Phlebotomine sandflies fauna (Diptera: Psychodidae) at rural settlements in the municipality of Cáceres, State of Mato Grosso, Brazil. Rev Soc Bras Med Trop 2012; 45(4): 437-443. PMid:22836661. http:// dx.doi.org/10.1590/S0037-86822012005000010 
Barbosa DS, Rocha AL, Santana AA, Souza CSF, Dias RA, CostaJúnior LM, et al. Soroprevalência e variáveis epidemiológicas associadas à leishmaniose visceral canina em área endêmica no município de São Luís, Maranhão, Brasil. Ciênc Anim Bras 2010; 11(3): 653-659. http:// dx.doi.org/10.5216/cab.v11i3.5933

Brasil. Guia de Vigilância Epidemiológica. Série A. Normas e Manuais Técnicos. Ministério da Saúde; 2009. Available from: ftp://ftp.cve.saude. sp.gov.br/doc_tec/zoo/lepto_gve7ed_atual.pdf.

Brasil. Manual de Vigilância e Controle da Leishmaniose Visceral. Ministério da Saúde; 2006. 122 p. Available from: http://bvms.saude.gov.br/bvs/ publicacoes/manual_vigilancia_controle_leishmaniose_visceral.pdf.

Costa PL, Dantas-Torres F, Silva FJ, Guimarães VCFV, Gaudêncio $\mathrm{K}$, Brandão-Filho SP. Ecology of Lutzomyia longipalpis in an area of visceral leishmaniasis transmission in north-eastern Brazil. Acta Trop 2013; 126(2): 99-102. PMid:23369878. http://dx.doi. org/10.1016/j.actatropica.2013.01.011

Felipe IMA, Aquino DMC, Kuppinge O, Santos MDC, Rangel MES, Barbosa DS, et al. Leishmania infection in humans, dogs and sandflies in a visceral leishmaniasis endemic area in Maranhão, Brazil. Mem Inst Oswaldo Cruz 2011; 106(2): 207-211. PMid:21537682.

Galati EAB, Nunes VLB, Rego FA Jr, Oshiro ET, Chang MR. Estudo de flebotomíneos (Diptera: Psychodidae) em foco de leishmaniose visceral no Estado de Mato Grosso do Sul. Rev Saúde Pública 1997; 31(4): 378-390. PMid:9595767. http://dx.doi.org/10.1590/S0034-89101997000400007

Guimarães KS, Batista ZS, Dias EL, Guerra RM, Costa AD, Oliveira AS, et al. Canine visceral leishmaniasis in São José de Ribamar, Maranhão state, Brazil. Vet Parasitol 2005; 131(3-4): 305-309. PMid:15967576. http://dx.doi.org/10.1016/j.vetpar.2005.05.008

Instituto Brasileiro de Geografia e Estatística - IBGE. Estimativa populacional [online]. 2012. [citado $2013 \mathrm{Fev}$ 10]. Available from: http://www.ibge.gov.br.

Machado TO, Bragança MAL, Carvalho ML, Andrade JDA Fo. Species diversity of sandflies (Diptera: Psychodidae) during different seasons and in different environments in the district of Taquaruçú, state of Tocantins, Brazil. Mem Inst Oswaldo Cruz 2012; 107(7): 955-959. PMid:23147157. http://dx.doi.org/10.1590/S0074-02762012000700021

Maia-Elkhoury ANS, Alves WA, Sousa-Gomes ML, Sena JM, Luna EA. Visceral leishmaniasis in Brazil: trends and challenges. Cad Saude Pública 2008; 24(12): 2941-2947. PMid:19082286. http://dx.doi. org/10.1590/S0102-311X2008001200024

Mestre GLC, Fontes CJF. A expansão da epidemia da leishmaniose visceral no Estado de Mato Grosso, 1998 - 2005. Rev Soc Bras Med Trop 2007; 40(1): 42-48. http://dx.doi.org/10.1590/S003786822007000100008
Missawa NA, Maciel GBML. Distribuição espacial de Lutzomyia longipalpis (Lutz \& Neiva, 1912) e Lutzomyia cruzi (Mangabeira, 1938) no Estado de Mato Grosso. Rev Soc Bras Med Trop 2006; 39(4): $337-$ 340. PMid:17119747. http://dx.doi.org/10.1590/S003786822006000400004

Missawa NA, Maciel GBML. List of species in the genus Lutzomyia, França, 1924 (Psychodidae, Phlebotominae) from the State of Mato Grosso. Rev Soc Bras Med Trop 2007; 40(1): 11-14. http://dx.doi. org/10.1590/S0037-86822007000100002

Missawa NA, Veloso MAE, Maciel GBML, Michalsky EM, Dias ES. Evidência de transmissão de leishmaniose visceral por Lutzomyia cruzi no município de Jaciara, Estado de Mato Grosso, Brasil. Rev Soc Bras Med Trop 2011; 44(1): 76-78. PMid:21340413. http://dx.doi.org/10.1590/ S0037-86822011000100017

Oliveira GMG, Figueiró EA Fo, Andrade GMC, Araújo LA, Oliveira MLG, Cunha RV. Flebotomíneos (Diptera: Psychodidae: Phlebotominae) no município de Três Lagoas, área de transmissão intensa de leishmaniose visceral, Estado de Mato Grosso do Sul, Brasil. Rev Pan-Amaz Saúde 2010; 1(3): 83-94.

Prado PF, Rocha MF, Sousa JF, Caldeira DI, Paz GF, Dias ES Epidemiological aspects of human and canine visceral leishmaniasis in Montes Claros, State of Minas Gerais, Brazil, between 2007 and 2009. Rev Soc Bras Med Trop 2011; 44(5): 561-566. PMid:22031070. http:// dx.doi.org/10.1590/S0037-86822011000500006

Rangel O, Sampaio SMP, Ciaravolo RMC, Holcman MM. The distribuition pattern of Lutzomyia longipalpis (Diptera: Psychodidae) en the peridomiciles of a sector with canine and human visceral leishmaniasis transmission in the municipality of Dracena, São Paulo, Brazil. Mem Inst Oswaldo Cruz 2012; 107(2): 163-169. PMid:22415253. http://dx.doi. org/10.1590/S0074-02762012000200003

Rey L. Parasitologia. 3th ed. Guanabara Koogan; 2001.

Santos SO, Arias J, Ribeiro AA, Holffmann MP, Freitas RA, Malacco MAF. Incrimination of Lutzomyia cruzi as a vector of American Visceral Leishmaniasis. Med Vet Entomol 1998; 12(3): 315-317. PMid:9737605. http://dx.doi.org/10.1046/j.1365-2915.1998.00104.x

Vilela ML, Azevedo CG, Carvalho BM, Rangel EF. Phlebotomine fauna (Diptera: Psychodidae) and putative vectors of Leishmaniases in impacted area by hydroelectric Plant, State of Tocantins, Brazil. PLoS One 2011; 6(12): e27721. PMid:22163271 PMCid:PMC3233550. http://dx.doi.org/10.1371/journal.pone.0027721

Young D, Duncan MA. Guide to the identification and geographic distribuition of Lutzomyia sand flies in México, the West Indies, Central and South America (Diptera:Psychodidae). Associated Publishers American Entomological Institute; 1994. 